\title{
INSIDER TRADING ANALYSIS OF FINANCIAL STATEMENTS ON MANUFACTURING COMPANIES IN INDONESIA STOCK EXCHANGE
}

\author{
Pracita Sri Ayu \\ Faculty of Economic and Business, University of Airlangga, Indonesia \\ E-mail: ayu.prachita@gmail.com
}

\begin{abstract}
The purpose of this study was to determine the effect of DSRI, GMI, AQI, SGI, and TATA variables on financial report fraud and to determine the relationship between insider trading and financial report fraud. The sample used is a company that publishes financial statements in 2014-2017 and information related to insider trading. This study uses logistic regression statistical methods. The results of this study were that the DSRI and SGI variables did not significantly affect fraud and the variables GMI, AQI and TATA significantly affected financial statement fraud. And insider trading has no significant correlation or correlation with financial statement fraud. the conclusion of this study is that not all variables affect financial statement fraud and there is no relationship between insider trading and financial statement fraud.
\end{abstract}

\section{KEY WORDS}

Financial report fraud, insider trading, index benefit ratio.

The financial statements are prepared with the intention to provide financial information for a company to the parties who use financial statements as consideration for making decisions. In the financial statements there are many problems in it, one of which is crime in the financial statements that currently occurs a lot. As for accounting crimes, there are no books or academic literature that specifically use this term. Crimes involving accounting science are often referred to as financial scandals or accounting scandals (Nugraha and Henny, 2015).

Accounting scandals or corporate accounting scandals are political and business scandals that arise with the disclosure of the misdeeds of executives of public companies. These crimes usually involve complex methods to misuse funds or mislead, overstate income, reduce costs, overstate the value of company assets or reduce reporting on the amount of liability, sometimes they also cooperate with officials in other companies or issuers concerned. When referring to the understanding of the accounting scandal above, accounting crimes tend to be closer to the term fraud which is related to the presentation of financial statements (Fraudulent Financial Statement) (Hutomo, 2012). Fraudulent Financial Statement is intentional misstatement or negligence, whether in terms of quantity or disclosure of financial statements intended to deceive users of financial statements, in this case the management processes financial statements for their own benefit. In general, accounting crime itself can be defined as a crime / fraud committed in the economic field and related to accounting. This means financial statement fraud is one form of accounting crime (Prakoso, 2009).

Accounting crime or accounting scandals involve business elites and professionals. An example of a popular case abroad is the Enron case where the company's stock price plummeted due to the act of Enron founder, former CEO, other enron executives and public accounting firm Arthur Anderson who conspired to commit Enron's financial report fraud (Kusmayadi, 2009). Accounting crimes in banks and in the capital market also involve professionals. By looking at the perpetrators, it was concluded that these accounting crimes fall into the category of white collar crime. This is in line with opinions (Sutherland, 1940 in Alalehto, 2015) which states that white collar crime is a crime committed by respectable people and high social status in relation to its occupation.

In Indonesia, accounting fraud is also common at the level of companies, both private and government companies. On December 6, 2012, Indonesia's score in the Corruption Perception Index (CPI) was 32 and was ranked 118 out of 176 countries measured by corruption. In this case, it can be seen from the number of cases related to corruption issues and fraudulent practices such as the liquidation of several banks, the proposed management of state-owned enterprises and the private sector to the courts, cases of banking crimes, tax manipulation, etc. (Wilopo, 2006).

In 2011, a fraud scandal occurred by PT Kimia Farma Tbk. PT Kimia Farma is an SOE whose shares have been traded on the stock exchange so that it becomes a public company. Based on a statement by the Ministry of BUMN and Bapepam's examination found misstatements in the financial statements that resulted in overstatement of net profit for the year ended 31 December 2011 amounting to Rp 32.7 billion which constituted $2.3 \%$ of sales and $24.7 \%$ from net income. This 
misstatement occurred by exaggerating sales and inventory at 3 business units, and was carried out by inflating the inventory price authorized by the production director to determine the inventory value at PT Kimia Farma's distribution unit as of December 31, 2011. In addition, the management of PT Kimia Farma also records double sales of 2 business units carried out on units that are not sampled by external auditors (Parsaoran, 2009).

In the journal Beneish (1999), conducts research on quantitative differences between public companies that manipulate financial statements and companies that do not. Beneish (1999) uses financial statement data from all companies listed in the COMPUSTAT database in 1989-1992. Beneish (1999) indicates that the likelihood of fraud is marked by an extraordinary increase in receivables, deterioration in gross margins, decrease in assets, sales growth, and increasing accruals. Beneish (1999) used variables of Days Sales In Receivables Index (DSRI), Gross Margin Index (GMI), Asset Quality Index (AQI), Sales Growth Index (SGI), Depreciation Index (DEPI), Sales General And Administrative Expenses Index (SGAI ), Leverage Index (LVGI), and Total Accruals to Total Assets Index (TATA), as predictors for detecting fraud. By using these variables, Beneish (1999) was able to identify $76 \%$ of sample companies cheating on their financial statements. Beneish (1999) also states that the variables DSRI, GMI, AQI, SGI, and TATA are significant variables in detecting possible fraud and are able to distinguish between companies that commit fraud and companies that do not commit fraud. Beneish (1999) suggested the use of accounting variables considered to have signals of future prospects as a technique for detecting fraud. This technique is based on the thought of the importance of information on a company that can capture the nature of the company's operations or activities economically and have economically reasonable detection capabilities (Yavida, 2001).

In the crime of financial statements is usually associated with insider trading activities that occur within the company. Therefore, it is necessary to determine whether the auditor can improve the ratio testing of financial statement crimes by including insider trading activities in this model using a sample consisting of companies found fraud and companies that have not found fraud in it (Scott and John, 1998 ) Insider trading crime is a white collar crime which is very dangerous for a regular market mechanism that is fair and efficient (Alahleto, 2015). Insider trading causes the price that is formed to be unnatural due to lack of information about the actual situation, but it is not easy to ensnare insider trading because the legal instruments of the capital market are less competitive with the rapid development of the capital market itself (Ardiansyah, 2014).

Not only in the capital market, there are insider trading practices, but also in companies listed on the Indonesia Stock Exchange, this practice has also occurred. Inside the company found fraud in insiders by reducing their ownership of the company's shares through a high level of sales activity that is measured by the number of transactions, and the number of shares sold (Scott and John, 1998). In addition, insider trading is also triggered by in (non-public) information banned by securities and exchange of actions. However, there are managers in companies that commit fraud in financial statements that tend to use their knowledge of fraud to protect or increase their wealth. Managers who issue misstatements of financial statements tend to protect or increase their wealth and based on their knowledge of the impact of fraud on the current financial statements that have not yet been revealed but they believe that the impact will eventually be revealed. Based on the above background, the authors are interested in conducting research on "Insider Trading Analysis of Financial Report Cheating on Manufacturing Companies in the Indonesia Stock Exchange".

Hypothesis. This study aims to examine and find empirical evidence of factors that influence financial statement fraud and whether these factors influence insider trading activities that commonly occur in the capital market. The following is a picture of a framework that shows the relationship between variables.

In connection with the importance of a method that can reflect the ability to detect fraud, this study uses index ratio analysis developed by Beneish. These variables are Days of Sales In Receivables Index (DSRI), Gross Margin Index (GMI), Asset Quality Index (AQI), Sales Growth Index (SGI), and Total Accruals to Total Assest Index (TATA). These variables are significantly able to detect whether the company is cheating or not on its financial statements, so that it can be known which companies are classified as companies that commit fraud and which companies are classified as not doing fraud (Efitasari, 2013).

H1a. Days of Sales In Receivables Index (DSRI) have a positive effect on financial report fraud.

H1b. Gross Margin Index (GMI) have a positive effect on financial report fraud.

H1c. Asset Quality Index (AQI) have a positive effect on financial report fraud.

$\mathrm{H} 1 \mathrm{~d}$. Sales Growth Index (SGI) have a positive effect on financial report fraud.

H1e. Total Accruals to Total Asset Index (TATA) have a positive effect on financial report fraud.

Insider trading is a form of crime that often occurs in the capital market, where the crime is committed by an insider from an issuer or public company that has inside information. This insider 
trading crime is very dangerous for the company and also the capital market because with the existence of insider trading crime this can make the company's performance deteriorate and also investor confidence will be reduced to the company. Therefore, how the company must be able to improve good control and also be supervised so that insider trading crimes do not occur in a company and also the capital market. Insider trading crime will also usually affect the company's finances where there is a fraudulent financial report so that the company's finances experience a decline in performance even if viewed from the greater level of investment and also the increasing ROA level (Scott and John, 1998). To examine the relationship between these insider trading activities and financial statement fraud, this study will test $\mathrm{H} 2$ as formulated as follows:

H2. There is a significant positive relationship between insider trading activities and financial statement fraud.

\section{METHODS OF RESEARCH}

Research Variables are objects of research that become the point of attention of a research. In this study, there are two variables, the dependent variable $(\mathrm{Y})$ which is financial report fraud and insider trading, while the independent variable $(X)$ is the days sales in receivables index (DSRI), gross margin index (GMI), asset quality index (AQI), Sales Growth Index (SGI), total accruals to total assets (TATA) to measure financial statement fraud and the number of shares and the number of transactions for purchases (Pmoney, Pshares, Ptrans) and sales (Smoney, Sshares, Strans), dollars and shares that traded (Nmoney, Nshares), the total number of stock transactions (Ttrans) to measure insider trading.

Dependent:

- Fradulent Financial Reporting. In this study financial report fraud (Fraudulent Financial Reporting) acts as the dependent variable. Cheating financial statements will be measured using the Beneish Ratio Index variable. According to (Beneish, 1999) there are 5 (five) significant variables to predict fraud in the financial statements. In this study I will use a dummy to measure variables categorized into 2 types of companies, namely companies that commit fraud because they violate Bapepam regulations given code 1 (one) and companies that do not commit fraud (nonfraud) are given a code of 0 (zero).

- Insider Trading. Insider trading in this study is the existence of an insider who trades in stocks with fraud, and by doing insider trading can get the results that are in accordance with what is desired. Insider trading will be measured using certain variables that have been determined in the study (Scott and John, 1998). And in this study will use logistic regression methods and correlation tests that can measure insider trading variables so that the results are obtained that there is a positive relationship between cheating financial statements with insider trading. Independent:

- Days Sales in Receivables Index (DSRI). DSRI is the ratio of the number os sales days in accounts receivable in the first year of manipulation (year $t$ ) to the previous year's measurement (year t-1).

$$
D S R I=\frac{\text { Account Receivable }_{t}-\text { Sales }_{t}}{\text { Account Receivable }_{t-1} / \text { Sales }_{t-1}}
$$

- Gross Margin Index (GMI). GMI is the ratio of gross margin in the previous year (year $\mathrm{t}-1)$ to the first year's gross margin of manipulation (year $\mathrm{t}$ ).

$$
G M I=\frac{\frac{\text { sales }_{t-1}-\text { Cost of Sales }_{t-1}}{\text { Sales }_{t-1}}}{\text { Sales }_{t}-{\text { Cost of } \text { Sales }_{t}}^{\text {Sales }}}
$$

- Asset Quality Index (AQI). AQI is the ratio of noncurrent assets (not including property, plants and equipment) to total assets, which measures the proportion of total assets to future profits that lack certainty.

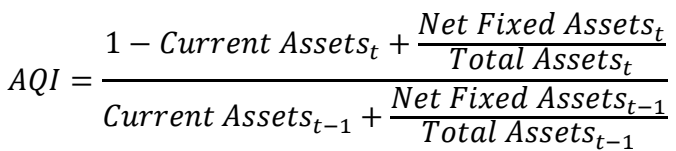


- Sales Growth Index (SGI). SGI is the ratio of sales in the first year of manipulation(year $t$ ) on sales of the previous year (year t-1).

$$
S G I=\frac{\text { Sales }_{t}}{\text { Sales }_{t-1}}
$$

- Total Accrual to Total Assets (TATA). TATA is the ratio of total accruals to total assets. Where total accruals are calculated as changes in working capital accounts other than cash and tax receivables minus depreciation.

$$
T A T A=\Delta \frac{\text { Working capital }-\Delta \text { Cash }-\Delta \text { Current Taxes Payable }- \text { Depreciation and Amortization }}{\text { Total Assets }}
$$

The number of shares and the number of transactions for buying and selling are obtained by looking at the data on the IDX website which have been listed annually. The number of transactions is the sum of all transactions carried out by the IDX and with external and internal parties. The number of shares and the number of transactions for purchases are the number of shares and also the number of transactions that can be used to assess the purchases that will be made by the IDX. Likewise with the number of shares and the number of transactions for sales is the amount between shares and transactions in the company that are valued for sales that will be carried out by the IDX. The value of the number of shares and the number of transactions for buying and selling are analyzed.

The definition of dollars and traded shares are dollars and shares traded are traded or traded, the value of the dollar and traded shares can assess the securities and exchange commission of the IDX. Dollar variables and traded shares act as independent variables that affect insider trading. Dollar values and shares traded are obtained from data listing on the IDX website.

The total number of stock transactions is the transaction of SEC (securities and exchange commissions) for which each sale and purchase has a record of the transaction made. The total number of transactions can assess an insider trading that occurs in the SEC so that in this study using a variable total number of stock transactions to measure insider trading. Variable total number of stock transactions as independent variables analyzed.

\section{RESULTS OF STUDY}

The test results from the table below can assess whether the model is fit, for the beginning part, the value of -2 Log likelihood which still only uses constants (c) is 261.751 while when it involves five independent variables (DSRI, GMI, AQI, SGI and TATA ), the value of -2 Log Likelihood is 226,281. This has shown a decrease in value when the independent variable is included, which is 261,751 $222,281=35,470$ according to the results in the Omnibus Tests of Coefficients table below.

For the beginning, it turns out that the coefficient of -2 Log Likelihood produced -0.457 which is greater than alpha $5 \%$ so that it can accept the null hypothesis that the model is fit. Furthermore, to block 1 of the second LogL -2 value is 226,281 smaller than alpha $5 \%$ so accept the null hypothesis, and the model is fit with the data.

Table 1 - Research Model

\begin{tabular}{|ll|l|l|l|}
\hline & Chi-square & df & Sig. \\
\hline \multirow{3}{*}{ Step 1 } & Step & 35,47 & 5 & 0 \\
& Block & 35,47 & 5 & 0 \\
& Model & 35,47 & 5 & 0 \\
\hline
\end{tabular}

\begin{tabular}{|ll|l|l|l|l|l|l|l|}
\hline \multirow{2}{*}{ Iteration } & \multirow{2}{*}{-2 Log likelihood } & \multicolumn{4}{l|}{ Coefficients } & AQI & SGI & TATA \\
\cline { 4 - 9 } & & & 230,402 & Constant & DSRI & GMI & AQI \\
& 2 & 227,198 & $-3,24$ & 0 & 0,001 & 2,422 & 0,009 & 0 \\
\multirow{4}{*}{ Step 1 } & 3 & 226,73 & $-4,422$ & 0 & 0,001 & 3,383 & 0,014 & 0 \\
& 4 & 226,437 & $-4,651$ & 0 & 0,001 & 3,571 & 0,019 & 0 \\
& 5 & 226,283 & $-4,7$ & 0 & 0,001 & 3,612 & 0,023 & 0,001 \\
& 6 & 226,281 & $-4,778$ & 0 & 0,002 & 3,68 & 0,026 & 0,001 \\
& 7 & 226,281 & $-4,791$ & 0 & 0,002 & 3,691 & 0,027 & 0,001 \\
& 7 & $-4,791$ & 0 & 0,002 & 3,691 & 0,027 & 0,001 \\
\hline
\end{tabular}

Source: Data Processing Results, 2017. 
From testing the data that has been done using IBM SPSS version 20 application, if in logistic regression use Cox \& Snell and Nagelkerke R Square. Then the Likelihood results obtained, can be seen in the table below:

Table 2 - Likelihood results

\begin{tabular}{|c|c|c|c|}
\hline Step & -2 Log likelihood & Cox \& Snell R Square & Nagelkerke R Square \\
\hline 1 & $226,281^{\mathrm{a}}$ & 0,166 & 0,225 \\
\hline
\end{tabular}

Source: Data Processing Results, 2017.

The test results in the summary model obtained a Log likelihood value of $-2.28,281$ with a significance of Hosmer and Lemeshow of 0.139 menunjukkan 0.05 indicating a regression equation with DSRI, GMI, AQI, SGI and variable in the equation variables.

After getting the results of the likelihood function to find out whether the variables can be used in this study, the next step is to test the hypothesis with the Hosmer and Lemeshow Test to test the feasibility of the regression model based on the hypothesis of this study. The following are the results of the Hosmer and Lemeshow Test:

Table 3 - Hosmer and Lemeshow Test Results

\begin{tabular}{|c|c|c|c|}
\hline Step & Chi-Square & Df & Sig. \\
\hline 1 & 12,285 & 8 & 0,139 \\
\hline
\end{tabular}

Source: Data Processing Results, 2017.

From the results of the Hosmer and Lemeshow Test listed above, it shows that the significance value (probability) is 0,139 or $13.9 \%>5 \%$, so Ho is accepted, meaning fraud that occurs in a company is influenced by DSRI, GMI, AQI, SGI and TATA, this also shows that a binary regression model is appropriate to use for subsequent analysis.

After getting the results of the Hosmer and Lemeshow Test above, the next step is to look at the Output Variables in the Equation to find out the regression coefficients of each of the independent variables and their constants. From the Output Variable in the Equation below shows the regression coefficient value of each independent variable and its constant in this study, namely:

- DSRI variable regression coefficient $(X 1)=0,000$ significance $=0.714$ or $71.4 \%>5 \%$ means that the DSRI variable does not significantly affect fraud that occurs in a company.

- The variable regression coefficient value of $\mathrm{GMI}(\mathrm{X} 2)=0.002$ significance $=0.333$ or $33.3 \%$ $<5 \%$ means that the GMI variable does not significantly affect fraud that occurs in a company.

- $\mathrm{AQI}$ variable regression coefficient $(\mathrm{X} 3)=3.691$ significance $=0,000$ or $0.00 \%<5 \%$ means that the AQI variable significantly influences fraud that occurs in a company.

- $\mathrm{SGI}$ variable regression coefficient $(X 4)=0.027$ significance $=0.747$ or $74.7 \%>5 \%$ means that the SGI variable does not significantly affect fraud that occurs in a company.

- TATA variable regression coefficient (X5) $=0.001$ significance $=0.396$ or $39.6 \%<5 \%$ means that the TATA variable does not significantly affect fraud that occurs in a company.

- The value of the regression coefficient constant $(a)=-4,791$ significance $=0,000$ or $0,00 \%$ $<5 \%$ means that the constant coefficient value significantly affects fraud that occurs in a company. Here is the Output Variables in the Equation:

Table 4 - Output Variables

\begin{tabular}{|ll|l|l|l|l|l|l|}
\hline & & \multicolumn{1}{c}{ B } & S.E. & \multicolumn{1}{l|}{ Wald } & Df & Sig. & \multicolumn{1}{c|}{$\operatorname{Exp(B)}$} \\
\hline \multirow{4}{*}{ Step 1 } & DSRI & 0 & 0,001 & 0,135 & 1 & 0,714 & 1 \\
& GMI & 0,002 & 0,002 & 0,936 & 1 & 0,333 & 1,002 \\
& AQI & 3,691 & 0,848 & 18,961 & 1 & 0 & 40,077 \\
& SGI & 0,027 & 0,085 & 0,104 & 1 & 0,747 & 1,028 \\
& TATA & 0,001 & 0,001 & 0,72 & 1 & 0,396 & 1,001 \\
& Constant & $-4,791$ & 1,005 & 22,748 & 1 & 0 & 0,008 \\
\hline
\end{tabular}

Source: Data Processing Results, 2017.

Thus, not all five independent variables can be used as predictors of determining fraud that occurred or did not occur in a company. The regression equation is as follows: 


$$
\begin{gathered}
Y=a+b_{1} X_{1}+b_{2} X_{2}+b_{3} X_{3}+b_{4} X_{4}+b_{5} X_{5} \\
Y=-4,791+0,000 X_{1}+0,002 X_{2}+3,691 X_{3}+0,027 X_{4}+0,001 X_{5}
\end{gathered}
$$

Following research model $\mathrm{Ln} \mathrm{P} / 1-\mathrm{P}=-5.166+3.691$ and the interpretation of the results of this test is that the higher the AQI value, the tendency for fraud to occur in a company will increase.

Correlation is used to measure the relationship between two variables with a certain scale, in this study using Pearson two-tailed correlation because it is a parametric measurement and wants to know the relationship between two variables. The symbol for Pearson correlation "p" if measured in population and " $r$ " if measured in the sample. Pearson correlation has a distance between -1 and +1 . If the correlation coefficient is -1 , then the two variables studied have a perfectly negative linear relationship. And if the correlation coefficient is +1 , then the two variables studied have a perfectly positive linear relationship. If the correlation coefficient shows the number 0 , then there is no relationship between the two variables studied. Following is the correlation table that has been processed:

Table 5 - Correlation

\begin{tabular}{|l|l|l|l|l|l|}
\hline & DSRI & GMI & AQI & SGI & TATA \\
\hline Pearson Correlation & 1 &, 177 &,- 294 &,- 011 &, 011 \\
\hline Sig. (2-tailed) & &, 015 &, 000 &, 878 &, 877 \\
\hline Sum of Squares and Cross-products & 343624751,08 & 35698710,66 & $-22102,995$ & $-45002,696$ & 4459729,95 \\
\hline Covariance & 1837565,514 & 190902,196 & $-118,198$ & $-240,656$ & 23848,823 \\
\hline N & 188 & 188 & 188 & 188 & 188 \\
\hline
\end{tabular}

\begin{tabular}{|l|l|l|l|l|}
\hline Kecurangan & Pmoney & Pshares & Ptrans & Smoney \\
\hline, 088 &,- 087 &,- 105 &,- 053 &,- 088 \\
\hline, 230 &, 236 &, 152 & -467 &, 228 \\
\hline 10887,687 & $-5637113904,128$ & $-4820179629,653$ & $-190175368,824$ & $-3711201,608$ \\
\hline 58,223 & $-30144994,140$ & $-25776361,656$ & $-1016980,582$ & $-19845,998$ \\
\hline 188 & 188 & 188 & 188 & 188 \\
\hline
\end{tabular}

\begin{tabular}{|l|l|l|l|l|}
\hline Sshares & Strans & Nmoney & Nshares & Ttrans \\
\hline,- 107 &,- 053 &,- 087 &,- 105 &,- 019 \\
\hline, 142 &, 466 &, 236 &, 152 &, 800 \\
\hline$-3168418,011$ & $-125161382,930$ & $-15658797,874$ & $-13388867,733$ & $-2877618,870$ \\
\hline$-16943,412$ & $-669312,208$ & $-83736,887$ & $-71598,223$ & $-15388,336$ \\
\hline 188 & 188 & 188 & 188 & 188 \\
\hline
\end{tabular}

Source: Data Processing Results, 2017.

To do the first interpretation done is to see the strength of the relationship between each variable. From the table above, we can see the numbers of Pearson correlation coefficients on DSRI = $1, \mathrm{GMI}=, 177^{*}$, TATA $=, 011$ and cheating $=, 086$. This means that the correlation between DSRI, GMI, TATA and cheating variables has a correlation or perfectly positive linear relationship because it approaches the number 1 . The two-star sign $\left(^{* *}\right)$ on the GMI variable means a significant correlation in the significance number of 0.01 and has two-way possibilities ( 2- tailed). But if there are no two stars, then the significance is 0.05 .

The second stage is to see the significance of the relationship between the two variables, which figure is seen from its significance, the relationship between the fifteen variables above that have been processed shows the relationship between each variable because the significance is $\mathrm{GMI}=0.013>$ $0,000, \mathrm{AQI}=0,000<0,001, \mathrm{SGI}=0,878>0.001$, TATA $=0.880>0.001$, cheating $=0.230>0.001$, Pmoney $=0.466>0.001$, Pshares $=0.152>0.001$, Ptrans $=0.467>0.001$, Smoney $=0.228>0.001$, Sshares $=0.142>0.001$, Strans $=0.466>0.001$, Nmoney $=0.236>0.001$, Nshares $=0.152>0.001$, Ttrans $=0.800>0.001$. And if there are no two asterisks, then the significance is 0.05 . The relationship of each variable has two directions (2-tailed), which can be in the same direction and not in the same direction.

The next step is to look at the direction of the correlation between each variable. The direction of correlation seen from the correlation coefficient results is positive or negative, because the number of correlation coefficients is positive for $\mathrm{DSRI}=1, \mathrm{GMI}=, 177^{*}$, TATA $=, 011$ and cheating $=, 086$, then the correlation of each variable is unidirectional. That is, if the value of DSRI, GMI, TATA is high then the value of fraud will be high too. While the variables AQI, SGI, Pmoney, Pshares, Ptrans, Smoney, Sshares, Strans, Nmoney, Nshares and Ttrans have negative values so that the correlation of each variable is not in the same direction. 
The Influence of DSRI, GMI, AQI, SGI and TATA on Financial Report Fraud. Based on the results that have been found after processing the data, the significance value for the DSRI variable is 0.714 , the value is greater than $\alpha=0.05$ so the conclusion taken is accept $\mathrm{H} 0$, which means the DSRI variable does not have a significant effect on fraudulent financial statements. While for the regression coefficient that produces a number of 0,000 can be interpreted that the greater the value of the DSRI produced will not make fraudulent financial statements that occur in a company increases. These results state things that support previous research as stated by the first hypothesis that the average DSRI does not differ significantly and the pattern of abnormal accruals that are not in accordance with the established null hypothesis, it is possible that the model is not powerful to estimate the prospect signal in the future (Yavida \& Indra, 2011).

The significance value for the GMI variable of 0.333 is greater than $\alpha=0.05$ so the conclusion taken is accept $\mathrm{HO}$, which means that the GMI variable does not have a significant effect on fraudulent financial statements. While for the regression coefficient that produces a number of 0.002 , it can be interpreted that the greater the GMI value produced does not make fraudulent financial statements that occur in a company increases. The results of this study support previous studies that these results are consistent with companies that do not face the prospect of poor having smaller incentives for earnings manipulation (Beneish, 1999).

Furthermore, the significance value for the AQI variable of 0,000 is smaller than $\alpha=0.05$ so the conclusions taken are accept $\mathrm{H} 1$, which means that the $\mathrm{AQI}$ variable has a significant effect on fraudulent financial statements. While for the regression coefficient that produces a number of 3.691 it can be interpreted that the greater the AQI value generated will make the fraudulent financial statements that occur in a company increases. These results support previous studies that AQI has a significantly positive coefficient because it is consistent with the possibility of earnings manipulation to increase when companies change their accounting treatment from deferred costs (Beneish, 1999).

Significant value for SGI variable is 0.747 , the value is greater than $\alpha=0.05$ so the conclusion taken is accept $\mathrm{HO}$, which means that the variable SGI does not have a significant effect on fraudulent financial statements. And for the regression coefficient produces a number of 0.027 can be interpreted that the greater the SGI value generated will not make cheating financial statements that occur in a company increases. The results of this study support previous research that the SGI variable is consistent with the growth of companies that face slowing growth and have incentives to manipulate earnings (Beneish, 1999).

And finally the significant value for the TATA variable is 0.396 , the value is greater than $\alpha=0.05$ so the conclusion taken is accept $\mathrm{HO}$, which means that the TATA variable does not have a significant effect on fraudulent financial statements. While for the regression coefficient produces a number of 0.001 can be interpreted that the greater the resulting TATA value does not make fraudulent financial statements that occur in a company increases. These results support previous research that negative TATA is significant with fraud that has low cash in addition to accounting income (Beneish, 1999).

The results of this study partly support the research conducted by Beneish (1999), that the AQI variable has a significant effect on fraudulent financial statements that occur in a company, so it can be interpreted that the greater the AQI value generated will make the fraudulent value of the financial statements increase. The study considers that AQI has a significantly positive coefficient because it is consistent with the possibility of earnings manipulation to increase when companies change their accounting treatment from deferred costs. This study also supports the research conducted by Wells (2001) which states that fraud, by its nature, is easy to hide and difficult to detect by an entity that manipulates profits and detects only once which is possible to avoid the discovery of fraud that occurs at all.

Relationship between Insider Trading and Report Fraud. The second hypothesis states that insider trading variables that are processed have no correlation or relationship that occurs between insider trading and fraudulent financial statements, this study supports the research conducted by Scott \& John (1998) which states that each measure of insider trading activity based on each of the same events, so that the correlation between these variables is not significant. The Nmoney and Pmoney variables do not have a significant correlation, it indicates that insider trading sales activities can overwhelm or multiply purchasing activities.

For financial report variables, DSRI, GMI, TATA and cheating have a correlation or perfectly positive linear relationship because the coefficient numbers are close to number 1 . As for the variables AQI, SGI, Pmoney, Pshares, Ptrans, Smoney, Sshares, Strans, Nmoney, Nshares, Ttrans does not have a significant relationship or correlation because the resulting value is negative and not in the same direction. 


\section{CONCLUSION}

1. Days sales in receivables index (DSRI), Gross margin index (GMI), Sales growth index (SGI) and Total accruals to total asset index (TATA) do not have a significant effect on fraudulent financial statements. Asset quality index (AQI) has a significant influence on fraudulent financial statements. statements.

2. Insider trading does not have a correlation or positive relationship with fraudulent financial

The limitations of this study are, limited empirical studies that discuss insider trading relationships with fraudulent financial statements, make the insider trading variables used only limited to Pmoney, Pshares, Transfers, Smoney, Shares, Strans, Nmoney, Nshares and Ttrans that make no connection to fraudulent financial statements.

Based on the conclusions and limitations of the research described earlier, there are several suggestions that can be considered for use in future research, namely:

1. The object of research should be to use all companies that are on all IDXs so that the expected results can be maximized.

2. Trying to use other variables such as financial ratios to measure fraudulent financial statements, so that the results of the study are expected to be able to analyze factors that are more significant in influencing and can increase the value of fraudulent financial statements.

3. Further research is expected to be able to use other ways of measuring fraud and insider trading, so that later there will be many choices in measuring fraudulent financial statements and insider trading itself.

\section{REFERENCES}

1. Arens, Alvin A. Elder, Randal J. Beasley, Mark S. (2006). Auditing And Assurance Services, Twelfth Edition. PT. Gelora Aksara Pratama, Erlangga.

2. Alalehto.T. (2015). White Collar Criminals: The State of Knowledge. The open Criminology Journal 28-35

3. Ardiansyah, 2014, Insider Trading dalam Hukum Pasar Modal, Artikel

4. Asmoro, Argo. (2010). Analisis Pengaruh Rasio Keuangan Terhadap Prediksi Kondisi Bermasalah Pada Bank. Unversitas Diponegoro, Semarang.

5. Bahrul Ulum. (2015). Terjemah, Tafsir dan Analisa Ekonomi Surah Al-Baqarah Ayat 282. Artikel. (Diakses Tanggal 9 Maret 2016).

6. Buya Hamka. (2012). Tafsir Al Azhar, Al Qur'an surah Al-Muthaffifin 7-17. (Diakses Tanggal 9 Maret 2016).

7. Beneish, Messod D. (1999). The detection of Earnings Manipulation. Financial

8. Analysts Journal.

9. Cressey, D. (1953). Other people's money, dalam: "Detecting and Predicting Financial Statement Fraud: The Effectiveness of The Fraud Triangle and SAS No. 99, Skousen et al. 2009". Journal of Corporate Governance and Firm Performance. Vol. 13 h. 53-81.

10. Efitasari, Hema Christy. (2013). Pendeteksian Kecurangan laporan Keuangan ( financial statement fraud) dengan menggunakan Beneish Ratio Index pada perusahaan manufaktur yang Lisnting Bursa efek Indonesia Tahun 2010-2011. Universitas Negri Yogyakarta.

11. F.H. Buckley,et.al. (1988). Corporation: Principles and Policies Emond Montgomery. Toronto Canada.

12. Gagola, Antonius S.C. (2011). "Analisis Faktor Risiko Yang Mempengaruhi Kecenderungan Kecurangan Pelaporankeuangan Perusahaan Publik Di Indonesia”. Program Studi Magister Akuntansi program Pasca sarjana. Universitas Diponegoro

13. Hery, (2014). Analisis Laporan Keuangan. Jakarta, Bumi Aksara.

14. Harahap, Sofyan Syafri. (2012). Teori Akuntansi (edisi revisi 2011). Jakarta. Rajawali Pers.

15. Hutomo,Oki suryo, (2012). Cara Mendeteksi Fraudulent Financial Reporting dengan Menggunakan Rasio-rasio Financial. Semarang.

16. Hu, Jie. Noe, Thomas H, (1997). The Insider Trading Debate. Vol 82. No.4. Atlanta.

17. Hall, James A. Singleton, Tommie. (2007). Information Technology Auditing and Assurance: Audit Teknologi Informasidan Assurance. Salemba Empat, Jakarta

18. Ikatan Akuntansi Indonesia. (2009). PSAK No.1 (Revisi 2009) Penyajian Laporan Keuangan. Menteng Jakarta. 
19. Jogiyanto, (2007). Teori Portofolio dan Analisis Investasi. Edisi 2007. Cetakan Pertama. Yogyakarta. BPFE Yogyakarta.

20. Jensen, M.C. dan W.H. Meckling. (1976). "Theory of The Firm: Managerial Behaviour, Agency Cost, and Ownership Structure". Journal of Financial Economics. Vol. 3. No. 4, h. 305-360.

21. Kaligis,O.C. (2003). Insider Trading dan Manipulasi Pasar di Dalam Praktek Pasar Modal di Indonesia. Jakarta.

22. Kartikajati, Evita. (2014). Analisis Pengaruh Kinerja Keuangan terhadap Kondisi Kesulitan Keuangan Bank di Indonesia (pendekatan menggunakan metode regreso logistik). Universitas Diponegoro, Semarang.

23. Kusmayadi, Dedi. (2009). Kasus Enron dan KAP Arthur Endersen. Artikel.

24. Lusy Suprajadi. (2009). Teori Kecurangan, Fraud Awareness, dan Metodelogi untuk Mendeteksi Kecurangan Pelaporan Keuangan. Parahyangan.

25. Mamduh M.Hanafi, Abdul halim. (2012). Analisis Laporan Keuangan. Yogyakarta. Sekolah Tinggi IImu Manajemen YKPN.

26. Munawir. (2001). Analisis Laporan Keuangan. Yogyakarta: Liberty.

27. Norbarani, Listiana. (2012). Pendeteksian Kecurangan Laporan Keuangan dengan Analisis Fraud Triangle yang di adopsi dalam sas no. 99. Skripsi Mahasiswa Fakultas Ekonomika dan Bisnis. Universitas Diponegoro, Semarang.

28. Norim, Yavida. Kusuma, Indra Wijaya. (2001). Penggunaan Variabel Akuntansi untuk mendeteksi Earnings Management. Journal Akuntansi \& Manajemen

29. Nawari. (2010). Analisis Regresi dengan MS Excel 2007 dan SPSS 17. PT Elex Media Komputindo, Jakarta.

30. Nugraha, Noval Dwi Aditya. Henny, Deliza. (2015). Pendeteksian Laporan Keuangan Melalui Faktor Resiko, Tekanan dan Peluang berdasarkan press release OJK 2008-2012. Unversitas trisakti Jakarta.

31. O'Hara, Phillip Anthony, (2001). Insider Trading in financial markets: legality, ethics, efficiency. Australia.

32. Palayukan, tandi pada. Nasution, Bismar. Sunarmi. Siregar, Mahmul. (2013). Analisis Terhadap Larangan Praktik Insider Trading Di Pasar Modal. USU Law Journal. Vol.II-No.2.

33. Prakoso, Elang Widya. (2009). Analisa Indeks Ratio untuk Mendeteksi Fraud (Penyimpangan/kecurangan) Laporan Keuangan (Studi kasus pada Perusahaan yang listing di Bursa Efek Indonesia per Desember 2007). Yogyakarta.

34. Putri, Intan. (2014). Analisis Laporan Keuangan dalam Mengukur Kinerja Keuangan pada PT. Hanjaya Mandala Sampoerna tbk. Universitas Gunadarma, Jakarta.

35. Parsaoran, David. (2009). Skandal manipulasi Laporan Keuangan PT. Kimia Farma tbk. Artikel.

36. Robert W. McGee, (2008), Applying ethics to Insider Trading.

37. Ratmono,dwi. Dianny, Yuvita Avrie. (2014). Determinan Kecurangan Laporan Keuangan: Pengujian Teori Fraud Triangle. Journal Accounting. Universitas Diponegoro.

38. Ridwan S. Sundjaja dan Inge Barlian. (2003). Manajemen Keuangan. Edisi keempat. Jakarta: Literata Lintas Media.

39. Roger E. Meiner,et.al. (1991). Securities Regulation: Cases and Materials. Fourth Edition. West Publishing Co. St. Paul.

40. Sebayang, Mahmud. (2009). Larangan Insider Trading, artikel.

41. Sunyoto, Danang. (2011). Praktik SPSS untuk Kasus. Nuha Medika, Yogyakarta.

42. Santoso,Singgih. (2003). Statistik Deskriptif: Konsep dan Aplikasi dengan Microsoft Exel dan SPSS. Yogyakarta.

43. Sastro Herbeth Simamora. (2010). Analisis Kinerja Laporan Keuangan Perusahaan untuk Keputusan dalam Pemberian Kredit Modal Kerja. Universitas Gunadarma, Jakarta.

44. Sofyan Syafri Harahap. (2009). Analisis Kritis Atas Laporan Keuangan. Rajawali Press, PT Rajagrafindo persada.

45. Syprianus Aristeus, S.H.,M.H. (2011). Penegakkan Hukum Terhadap Insider Trading di Pasar Modal dan Upaya Perlindungan terhadap Investor. Jakarta.

46. S. Munawir. (2010). Analisis Laporan Keuangan. Yogyakarta: Liberty.

47. Summers, Scott L. Sweeney, John T dalam Loebbecke.J.K, and J.J Willingham, Jr. (1998). Review of SEC accounting and auditing enforcement release, working paper. University of Itah, Salt lake City, UT.

48. Scott, L Summers. John, T Sweeney. (1998). Fraudulently Misstated Financial Statements and Insider Trading: An Empirical Analysis. Vol. 73. Columbia.

49. Sukirman. Sari,Maylia Pramono, (2013). Model Deteksi Kecurangan Berbasis Fraud Triangle. Universitas di ponegoro. Semarang. 
50. Theodorus M. Tuanakotta. (2012). Akuntansi Forensik \& Audit Investigatif. Jakarta. Salemba Empat.

51. Wells, Joseph T. (2001). Irrational Ratios. Journal of Accountancy Agt-2001.

52. Wilopo. (2006). Analisis Faktor-faktor yang Berpengaruh terhadap kecenderungan Kecurangan Akuntansi: Studi pada Perusahaan Publik dan Badan usaha milik Negara di Indonesia, Simposium Nasional Akuntansi 9 Padang.

53. Undang-undang Republik Indonesia. (1995). Undang Undang Pasar Modal. Pasal 95-99 dan pasal 104.

54. Kitab Undang-Undang Hukum Pidana pasal 362, 368, 372, 378, 396, dan 406.

55. Dr. Abdullah bin Muhammad bin Abdurahman bin Ishaq Al-Sheikh. (Mei 2003). Lubaabut Tafsiir Min Ibni Katsiir (Tafsir Ibnu KatsirJilid 5). Pustaka Imam asy-Syafi'i. Bogor. 